\title{
SOBRE QUANDO SE MORRE E OUTRAS COISAS
}

Francisco Neto Pereira Pinto ${ }^{1}$

\author{
Quando se morre vira santo \\ Histéricas aos prantos \\ Indiferença e burburinhos tantos
}

Morreu o Pedro e para o velório se reuniram a desocupada vizinhança especialmente no cair da noite Não era tanto uma questão de consideração para com o morto ou solidariedade à família mas uma quebra na rotina evitação do tédio e evidentemente um bônus de likes nas redes sociais Alguém segurava a mão da mãe enlutada que já sofreu a lot pelas danações do filho e agora revisava uma a uma as falhas possíveis e imaginadas Difícil era saber qual a maior dor na escala métrica dos sofrimentos se a dor pela perda ou as patadas da culpa que lhe vinha ferroar com a fúria de dezenas de escorpiões vermelhos Não tinha ânimos para os gritos e já tão esmorecidas de lágrimas Dona Sebastiana sangrava quietinha e calada Ana não tinha tempo de sofrer pelo irmão pois estava muito ocupada prestando informações sobre como morreu tão de repente o Pedro pois era rapaz saudável e até outro dia não mostrava sinal algum de sofrer doença do coração Pois é foi de repente jogando bola não havia mais nada que pudesse fazer a equipe do Samu dizia a um vizinho parente ou amigo Depois fazia cafés e providenciava uns biscoitos Suava tinha palpitações e de tempos e tempos tinha crises de choro Seu Romão o pai dizia palavras poucas e esparsas e ocupava-se com questões legais e relacionadas ao velório e ao enterro Sentia um aperto no peito mas acreditava ser aquilo tudo um sonho ruim e quando amanhecesse tudo estava na mesma Às $21 \mathrm{~h}$ chegou aquela vizinha da rua de cima uma magra alta de cabelos cumpridos olhos verdes lânguidos e de braços finos e longos Jogou-se ao prantos no abraço não sabia de quem mas repetia esbaforida que o conhecia desde sempre um menino bom respeitoso obediente Com uma vida toda pela frente $O h$ God Não não podia ser Às $22 \mathrm{~h}$ veio ainda pálida da surpresa uma amiga de escola com quem fez uma série não sabia

\footnotetext{
${ }^{1}$ Doutorando e Mestre em Ensino de Língua e Literatura pela Universidade Federal do Tocantins, campus de Araguaína, e professor adjunto no Instituto Tocantinense Presidente Antônio Carlos, campus de Araguaína. Faz formação em Psicanálise pelo IPLA, Instituto da Psicanálise Lacaniana.
} 
dizer ao certo qual ainda no ensino médio Estarrecida em choque lançou-se sobre o caixão e se não a tivessem segurado teria beijado na boca do morto Suspeitava seriamente que por ela teria tido uma queda e agora como ela poderia conviver com tamanha culpa Não não o deixaria partir sem antes beijá-lo e dizer-lhe que muito inexperiente ainda bobinha era muito tímida não sabia como reagir mas que secretamente só para si o achava muito bonito O tempo ah se pudesse voltar no tempo Acode segura gritou uma voz do outro lado do caixão que a moça está passando mal Não na verdade desmaiou é preciso levá-la ao hospital

Pedro foi enterrado no cemitério municipal às $9 \mathrm{~h}$ do outro dia e as últimas palavras que se ouviu foi de sua mãe dizer Pedro perdoa seus irmãos João e Maria que não apareceram

A morte é um mistério

que a ninguém mais encanta

mas que da vida a existência decanta 